\title{
Knowledge is everywhere: a philosophical exploration
}

\author{
CS DE BEER *
}

\begin{abstract}
In this article, I would like to argue that interdisciplinarity belongs to the very nature of knowledges in their diverse manifestations and any disregard for this idea would mean a distortion of knowledge while creating at the same time a situation that puts not only individuals but humanity in general in danger. The role of myths, paradigms, the position beyond-method, and the impact and interference of knowledges on each other, that illustrate the point of a universally distributed intelligence, is used as arguments in the development of this statement. The nature and scope of the danger is spelled out as well. Ways and strategies are proposed that should be invented to avoid this danger for the well-being of all human beings in their societies.
\end{abstract}

\section{Keywords}

Transdisciplinarity, knowledge, myths paradigms, methodology, beyond-method, royal science, nomad science, ambulant science, creativity.

\section{Disciplines}

Philosophy and Theories of science.

Prof. CS ( Fanie) de Beer is attached to the division for Information Science, University of Pretoria, Pretoria, South Africa. 


\section{Universally distributed intelligence}

The guideline that will be followed in this argument is the assumption that the notion of "a universally distributed intelligence" is of central importance and highly significant.

All human beings, wherever and whenever they are, are equipped with intelligence, in other words have the ability to know, the keenness to develop knowledge, and an urgency to use knowledge. (See Pierre Lévy in this regard). His formulation reads as follows:

No one knows everything, everyone knows something, all knowledge resides in humanity .... If you are tempted to judge someone as ignorant, look for the context in which his knowledge can be turned into gold" (Lévy 1997:13-14).

Knowledge is simply everywhere. Lévy discusses this idea under the important notion of "collective intelligence" and then he adds:

The basis and goal of collective intelligence is the mutual recognition and enrichment of individuals rather than the cult of fetishized or hypostatized communities.

Again

The ideal of collective intelligence implies the technical, economic, legal and human enhancement of a universally distributed intelligence that will unleash a positive dynamic of recognition and skills mobilization (p. 15).

\section{Science and its limitations: a position beyond and outside science}

Knowledge is not limited to science and scientific disciplines as valuable forms of knowledge, and more specifically not to any particular scientific approach of which there are many. Even scientific method is not adequate to exhaust all knowledge possibilities.

There is knowledge outside science; there is also scientific knowledge outside certain definitions of what scientific knowledge entails.An approach that may be called "beyond-method" should complement the work done in terms of scientific method. Edgar Morin and Michel 
Serres made significant contributions in this regard. Serres made the following remark on method:

I do not seek, I find - and only write if I find. Nothing in my books, in any place, is revived from elsewhere. What is livelier, at the first break of dawn, than the improbable unexpectedness, so alert to time, of finding? Who is more profoundly boring than the repetitive reasoner who copies or seems to construct by constantly repositioning the same cube? Ruminating on the past - what a system! Repeating a method what laziness! Method seeks but does not find (1997:100).

This approach leads to valid and highly significant knowledges that emerge in the spaces between disciplines, outside disciplinary boundaries, and independent of specific disciplines. It is of immense importance to attend to the ecology of knowledges and the role it plays in the construction of knowledge outside the scope of method.Deleuze and Guattari's views on the nomad sciences, supports these views. Cf the discussion of Stengers (2000:150-166) on Deleuze and Guattari.

\section{Royal and nomad sciences}

Deleuze and Guattari (1987) distinguishes between "royal" sciences and the "ambulant" or "nomad" sciences that preceded it.

\footnotetext{
Royal science is inseparable from a hylomorphic model implying both a form that organises matter and a matter prepared for a form (Deleuze and Guattari 1987:174).
}

'Royal science' does not make the "ambulant" or "nomad" sciences that preceded it disappear. The latter do not link science and power together, they do not destine science to an autonomous development, because they were in solidarity with their terrain of exploration, because their practices were distributed according to the problems provoked by a singularized material, without having the power to assess the difference between what, from singularities, refers to "matter itself" and what refers to the convictions and ambitions of the practitioners (belonging henceforth to the second world). Royal science "mobilizes" the ambulent process. 
In the field of interaction of the two sciences, the ambulant sciences confine themselves to inventing problems whose solution is tied to a whole set of collective, non-scientific practices but whose scientific solution depends, on the contrary, on royal science and the way it has transformed the problem by introducing it into its theorematic apparatus and its orhganization of work (Ibid 374).

Compare further the discussion of this issue by Stengers (2000:150166). What is implicitly suggested by these different views of science is the deeper origins of knowledge that takes to the complex notion of paradigm.

\section{The paradigmatic knot}

Although we are all familiar with Thomas Kuhn and the importance of the notion of paradigm there exists some very naïve and strangely sedimented views on paradigm and its place and role in scientific work. Here our attention is drawn to another emphasis put on the notion of paradigm that differs substantially from the views of Kuhn and some reflections in the extension of Kuhn's work. For Edgar Morin paradigm, lies at the heart of knowledge, but then knowledge understood as more than merely scientific explorations. Morin uses this notion to describe the deepest thinkable origins of knowledge before disciplinary boundaries and the demarcation of fields, very often artificially and politically inspired, were finalised or pursued. He writes that the notion is profoundly immersed in individual and collective unconscious and its recent emergence in conscious thought is still very hazy and foggy. It refers us to its multiple rootedness in the linguistic, logical, ideological, and even more profoundly in cerebro-psychic and sociocultural facets of human knowledge. For this reason the term "paradigm" is used not only for scientific knowledge, but for all knowledge, all thought, and every noological system. (Morin 1991:213). He offers the following definition:

\footnotetext{
A paradigm contains for all discourses that effectuates itself under its empire, the fundamental concepts or master categories of intelligibility at the same time as the type of logical relations of attraction/rejection (conjunction, disjunction, implication or others) between concepts and categories. Thus, individuals know, think, and act according to the paradigms that are culturally inscribed in them. The systems of ideas are radically organised in virtue of paradigms (Ibid).
}

One significant implication of this definition is not only that valid 
and useful knowledge cannot be limited to scientific knowledge only, defined in a certain way, but also that knowledge is not limited to Western culture. Knowledge is everywhere. This definition takes Morin to the idea of a Gordian knot where everything is tied together [referring to the human and the natural sciences]". He then continues:

\footnotetext{
[I]t may also be assumed that these determinations, which coagulate and agglomerate in any field of knowledge, thought, inquiry, that all these immediacies which interfere, are also, in a certain way, fundamentally related in deep structure, and that the Gordian knot of these multiple interrelations between various insistencies which govern knowledge, also control an underlying nucleus where ... strong forces are at work (Morin 1983:12).
}

In the widest possible sense, as Morin (1991:222) puts it at a later stage, the universe of religion, of mysticism, of poetry, of literature, of ethics, of metaphysics, of private life, of exaltation, of sentiment, of love, of passion become the de facto complement, the necessary counter weight to the hyper-objective, pragmatic, empiric, prosaic, technical and bureaucratic universe. For more about this formidable paradigmatology his fine book on ideas should be studied.(See Morin 1991: 211-238). Equally relevant in this context is his differentiation between "the paradigm of simplicity" and "the paradigm of complexity" (Morin 1990:304-305).

\section{Science and myth}

The consideration of the ecology of the sciences and of paradigmatology emphasises the importance of taking a much wider discursive look at knowledge generation than what science in the classical sense allows. The following significant remark by Michel Serres, himself a philosopher of science, will be accepted as a kind of guideline and point of departure for these reflections: "there is more myth in science than we are inclined to accept and more knowledge in myth or fiction than we are ready to agree to." This perspective is highly relevant for any thorough epistemo-critique as well as ontological exploration related to the crucial fields of knowledge creation, dissemination, usage and management. Look for example at Serres' study of the work of Emile Zola (Serres 1975). Knowledge is clearly everywhere, immaterial of the type of discourse we are thinking of or are engaged in. Theoretical and methodical imperialism is clearly the infantile sickness of knowledge in its first stages. (pp 13-14). Totalities seem to us incomprehensible except when it can be controlled. University work is separated into sects, reproducing 
streets and quarters, divisions and parties, an impossible art of living, not to say anything about thinking. Serres study of Zola is a substantial effort in breaking down this divisionary culture and an excellent demonstration of how this can be done.

\section{Interferences of knowledges}

Philosophy, science and literature should be seen, in view of this, as standing and moving in an interactive and interreferential knowledge fellowship, and not in separate and independent ways, in order to ensure the maximum in knowledge quality and scope. Interconcepts and vocabulary developments across disciplinary boundaries can assist immensely in this regard in an indispensable way. The interference of knowledges in each others domains can be of decisive importance. "Some, doubtless specialists in their field, had even understood, on their own, that each portion of their knowledge ... works at the intersection or the interference of many other disciplines and, sometimes, of almost all of them".

(Serres 1997:xvii). Interferences of this nature contribute to the enrichment of knowledges in all forms in a comprehensive sense.

As Serres states: interference should actually be read as interreference (Serres 1972). The strong point or argument in this book is the emphasis and demonstration of the collapse of disciplinary and encyclopaedic boundaries in terms of which knowledges are locked up in closed cells. He develops what he calls 'a philosophy of transport: intersection, intervention, interception'. (Serres 1972:10).

He should have added interference. This philosophy speaks of the sciences, but it is not silent about the world that it expresses or institutes, about the world of things and the world of humans. This philosophy takes cognisance of the always-present zones of shadow and margins of uncertainty that have a questioning impact on our knowledges, certainties, and dogmas. Against Bachelard's "new scientific spirit", Michel Serres baptised his approach as "the novel new scientific spirit". Hereby the focus is put on the multiple relations between domains and on the fact that so-called objective knowledge envelops implications that Serres designates as non-knowledge, or the unknown of the sciences.

Every regional epistemology is prisoner of its region. It should be realised that every region is a complexion, and connects in itself a variety of links, coming from all over the encyclopaedia or going everywhere. Each region is an intersection, a knot of interrelations, and contains interpretations of the totality of domains that it mobilises. 
What is experienced is an enlargement of traditional epistemology under the sign of multiplication. This offers the opportunity for surprising encounters that may lead to new and different knowledges. We encounter indeed a theory of information (Op cit 12-13). Account is given here not only of complexity, but also of intelligence. Intelligence is challenged to respond, true to its nature, and to make this nature true.

\section{The excitement of inventiveness}

Out of these fertile combinations highly necessary inventions are provoked that can change the world and that will open up possible futures. Invention takes place everywhere, especially where one does not expect it. Social, cultural, and electronic networks are immensely important in facilitating inventions of this nature. Deliberate strategies are required of which Bernard Tschumi is an excellent example. "Inventions tend to occur when unrelated areas, ideas, or forms come together in unexpected ways". This entails the disjunction of conventions and the use of concepts from diverse fields that enables us to relate any specific field with its outside.The problem with many retrieval and management issues pertaining to knowledge is the assumption that we re working on "already given entities". Knowledge is there. But knowledge is such a dynamic phenomenon that it can never be sedimented and given in any final sense. The superb alternative roles of retrieval and managerial endeavours are to make new combinations for new inventions possible, initiating precisely that. The focus of Michel Serres' philosophy of education can be summarised as follows: "The all-encompassing formation of human thought as invention, and vice versa, inventive creativity as the only creativity worthy of cognitive thought". (Assad 1999:128).

\section{The instructed third}

Special educational requirements corresponding to the abovementioned focus should be pursued and will be recommended for individuals to achieve this kind of inventive orientation towards knowledge. Michel Serres (1997) refers to this kind of qualified person as "the instructed third". "We must imagine a way in which to teach, with the same gesture, both the poem and the theorem, without wronging either and with mutual enrichment: experimentation and experience, the new world of scientists and the storytelling of time immemorial, the immortal world of scientific laws and the new age of the arts. Those taught the third approach to knowledge, born from this mixed school, will have chucked the death wish that makes us cut ourselves off, that puts our world in danger." 


\title{
The death wish: the real danger
}

Reluctance in pursuing interdisciplinarity and its implied inventions and hesitance in becoming adequately educated for this contains a danger, according to Serres. It represents for him "a death wish that makes us cut ourselves off, that puts our world in danger". Look at what Serres has in mind with this. He writes:

\begin{abstract}
Invention is the only true intellectual act, the only act of intelligence. The rest? Copying, cheating, reproduction, laziness, convention, battle, sleep. Only discovery awakens. Only invention proves that one truly thinks what one thinks, whatever that may be. I think therefore I invent, I invent therefore I think: the only proof that a scientist works or that a writer writes. Why work, why write otherwise? In all other cases, they sleep or fight and prepare to die badly. They repeat. The inventive breath alone gives life, because life invents. The absence of invention proves, by counterexample, the absence of work and of thought. The one who does not invent works somewhere other than in intelligence. Brutish. Somewhere other than life. Dead (Serres 1997:92-93).
\end{abstract}

Compare this also with the strong sense in which George Steiner (1999) speaks of "the barbarism of ignorance" and at an earlier stage his statement about Freud's death wish. Note also the voice of Edgar Morin (1991) added to these explicit voices.

The barbarism and the ignorance, and the barbarism of ignorance at issue here, are not negligible matters. They have everything to do with how we think about knowledge and kinds of knowledge, or denial of knowledges.

There is a strong suggestion in Steiner's work that "a longing for violent dissolution" is "a constant in the history of social and intellectual forms" under certain circumstances. With reference to insights of Freud and psychoanalysis, in general he emphasises the notion of a death- wish that is operative in both individual and collective consciousness as a philosophic trope and relate it to the tensions, which civilised manners impose on central, unfulfilled human instincts, that remains valid. "There is in human relations an inescapable drive towards war, towards a supreme assertion of identity at the cost of mutual destruction." (Steiner 1978:27). He refers to "this essential malaise". Intellect and feeling were fascinated by the prospect of a purging fire. What is experienced is the dissolution of civilized norms and of human hopes.

Edgar Morin (1991:245-7) refers to a fundamental and multidimensional aspect related to the problem of general problem solving. 
The human mind can easily be distracted, degraded and deregulated and by that demonstrating its lack at the same time of interior regulation (tendency to self-deception, lying to one-self) and noological regulation (a civilised noosphere). He calls this a historical problem and a civilisational pain. "We are still in the prehistory of ideas. We are always in the barbaric era of religions and of myths, and we have not quitted the hurricane-like era of ideologies."

Thorough noological investigations show us that our ideas are still barbaric, and that their relations with us are equally barbaric. We have believed that barbarism was to be found in the absurd myths of the past and the cruel religions from elsewhere. We have not understood that their barbarism have invaded our ideologies which have themselves engendered a specific, abstract, cold, anonymous barbarism. We have not understood that our reason, our science, our humanism, about which we believe that they are civilised and civilisers, were themselves overtaken by barbarism and that they suffocate the civilised/civilising source that was in them.

Barbaric is our idea that rationalism is rational, that science is only scientific, that humanism is humane. Certainly, it is not a matter of simply, in a naïve manner, eliminating myths, rendering our ideas purely and simply instrumental, purifying reason in order to arrive at a cognitive bliss where we possess uncontaminated truth. Such naïveté would itself be a sign of barbarism, testifying to the fact that we have not taken cognisance of the reality and complexity of the "anthropo-socio-noosphere". As far as we have not made progress in these relations we will remain in the era of barbaric ideas (doctrines, ideologies, reductive and mutilating ideas).

Now, this danger, which is very real, poses a great threat. It is born from a deep-seated inspiration, namely the will to ignorance as almost a defining principle of humans (Lacan and Felman). The important thing here would be to work out ways in which these threats (there must be clarity on the nature and seriousness of the threats, especially in view of the strength of the impulses of the will to ignorance that can be observed amongst academics as well as their students) can be countered.

However, let us first take a closer look at what is according to psychoanalysts at stake here. The discovery of the unconscious implies, according to Jacques Lacan, a specific way of understanding the cultural, pedagogical and epistemological revolution that is at issue here. "[T]he analytic learning process puts in question the traditional pedagogical belief in intellectual perfectibility, the progressivist view of learning as a simple one-way road from ignorance to knowledge." (Felman 1987:76). Learning proceeds not through linear progression but through breakthroughs, leaps, discontinuities, 
regressions, and deferred action. In this way, psychoanalysis institutes a unique way of learning: it gives access to information unavailable through any other mode of learning. Knowledge is everywhere, not only in the conscious awareness of the human subject.

The Hegelian concept of "absolute knowledge", the culmination of the Western approach to knowledge, has as its ideal the exhaustion, through methodical investigation, of all there is to know. Complete and totally appropriated knowledge will become, in all senses of the word, mastery. But the unconscious, in Lacan's conception, is precisely the discovery that human discourse can by definition never be entirely in agreement with itself, entirely identical to its knowledge of itself, since as the vehicle of unconscious knowledge, it is constitutively the material locus of a signifying difference from itself. The unconscious itself is a kind of unmeant knowledge that escapes intentionality and meaning, a knowledge spoken by the language of the subject (eg slips or dreams), but that the subject cannot recognise, assume as his and appropriate. "The discovery of the unconscious .... is that the implications of meaning infinitely exceed the signs manipulated by the individual." (Lacan 1978:150).

Against the dangers of ignorance, the death wish, and nihilism, the instructed third is called upon, to take care of us by continuously inventing and reinventing life.

\section{Bibliography}

Assad, ML. 1999. Reading with Michel Serres: an encounter with time. Albany" Suny Press.

Deleuze, G. \& Guattari, F. 1987. A thousand plateaus: capitalism and schizophrenia. Minneapolis: University of Minnesota Press.

Felman, S. 1987. Jacques Lacan and the adventure of insight: psychoanalysis in contemporary culture. Cambridge (Mass.): Harvard University Press.

Lacan, J. 1978. Le séminaire, livre II: Le moi dans la théorie de Freud et dans la technique psychanalytique. Paris: Seuil.

Lévy, P. 1997. Collective intelligence: mankind's emerging world in cyberspace. New York: Plenum Trade.

Morin, E. 1983. Social paradigms of scientific knowledge. SubStance, 39:3-20. 
Morin, E. 1990. Science avec conscience. Paris: Seuil

Morin, E. 1991. La méthode IV: Les idées - leur habitat, leur vie, leurs moeurs, leur organisation. Paris: Seuil.

Serres, M. 1972. Hermes II: L'Interférence. Paris: Minuit.

Serres, M. 1975. Feux et signaux de brume: Zola. Paris: Grasset.

Serres, M. 1997. The troubadour of knowledge. Ann Arbor: The University of Michigan Press.

Steiner, G. 1978. In Bluebeard's castle: some notes towards the redefinition of culture. London: Faber \& Faber.

Steiner, G. 1999. Barbarie de l'ignorance. La Tour d'Aigues: Editions de l'Aube.

Stengers, I. 2000. The invention of modern science. Minneapolis: The University of Minnesota Press. 